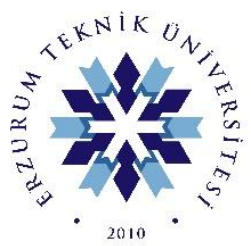

TOTALITTER DÜNYALAR: BİN DOKUZ YÜZ SEKSEN DÖRT VE $V$

\title{
TOTALITARIAN WORLDS: NINETEEN EIGHTY-FOUR AND V FOR VENDETTA
}

\author{
Gonca KARACA \\ Arş. Gör. Dr., Recep Tayyip Erdoğan Üniversitesi, Fen-Edebiyat Fakültesi, İngiliz Dili ve \\ Edebiyatı Bölümü \\ gonca.karaca@erdoğan.edu.tr \\ https://orcid.org/0000-0002-1013-7241
}
ETÜ Sosyal Bilimler Enstitüsü Dergisi | ETU Journal of Social Sciences Institute
S.14, Nisan | April 2022, Erzurum
e-ISSN: 2717 - 8706
Makale Türü | Article Types : Araştırma Makalesi|Research Article
Geliş Tarihi|Received Date $\quad$ : 07.09.2021
Kabul Tarihi|Accepted Date $\quad$ : 07.12.2021
Sayfa | Pages : $1-20$
doi : http://dx.doi.org/10.29157/etusbed.991757
https://dergipark.org.tr/etusbed
This article was checked by
$\boldsymbol{v}$ iThenticate



TOTALIITER DÜNYALAR: BİN DOKUZ YÜZ SEKSEN DÖRT VE $V^{1}$ Gonca KARACA

$\overline{\text { ETÜ Sosyal Bilimler Enstitüsü Dergisi (ETÜSBED), S. 14, Nisan 2022, Sayfa: 01-20 }}$

\section{ÖZ}

Totaliterlik sadece siyasal değil aynı zamanda sosyal ve kültürel alanlarda da önemli bir kavramdır. Vatandaşlar üzerinde toptan (total) iktidar uygulamayı amaçlayan totaliter rejimler genellikle distopik eserlerde resmedilmektedir. Bu türden distopyaların belki de en çok bilinen ve okunanı olan George Orwell'in yazdığı Bin Dokuz Yüz Seksen Dört mutlak siyasal otoriteye karşı güçlü eleştirisiyle birçok benzer eseri etkilemiş ve onlara ilham vermiştir. Böyle bir eser Alan Moore ve David Lloyd'un aynı isimli grafik romanından uyarlanan ve James McTeigue tarafından yönetilen $V$ filmidir. Bin Dokuz Yüz Seksen Dört gibi bu film de benzer bir totaliter yönetimi odak noktası yaparak ve yönetim sistemleri ile ilgili soruları gündeme getirerek distopik bir geleceği tasvir etmektedir. Totaliterliğe ilişkin olarak, Bin Dokuz Yüz Seksen Dört'te Okyanusya başında Büyük Birader'in bulunduğu ve basitçe adlandırılan Parti tarafından yönetilirken $V^{\prime}$ deki yönetici parti Norsefire' ın başında ise Adam Sutler bulunmaktadır. Bu türden benzerlikleri göz önüne alarak, bu çalışma, parti, ideoloji, gözetim, gizli polis, propaganda ve direniş gibi açılardan bu iki eserdeki totaliter sistemleri ortaya koymayı amaçlamaktadır.

Anahtar Kelimeler: Totaliterlik, distopya, gözetim, gizli polis, propaganda.

\section{TOTALITARIAN WORLDS: NINETEEN EIGHTY-FOUR AND V FOR VENDETTA}

\section{ABSTRACT}

Totalitarianism is a significant concept not only on political but also on social and cultural grounds. Totalitarian regimes, which aim to exercise total power over citizens, are generally portrayed in dystopian works. Perhaps, one of the most known and read dystopias of this kind, Nineteen Eighty-Four by George Orwell has influenced and inspired many other similar works through its powerful criticism of an absolute political authority. One such work is the movie $V$ for Vendetta directed by James McTeigue, being based on the graphic novel of the same name by Alan Moore and David Lloyd. The movie, like Nineteen Eighty-Four, depicts a dystopian future making a similar totalitarian rule its focus point and raising questions about ruling systems. With regard to totalitarianism, Oceania of Nineteen Eighty-Four is ruled by simply-called Party led by Big Brother while the ruling party Norsefire in V for Vendetta is headed by Adam Sutler. Taking into consideration such similarities, this study aims to put forward totalitarian systems of the two works concerning such elements as party, ideology, surveillance, secret police, propaganda and resistance.

Keywords: Totalitarianism, dystopia, surveillance, secret police, propaganda.

1 This article is the revised and expanded version of the paper presented at the "International Graduate Conference: Innovative Representations of 'Utopias' in Studies in English" held on 15-16 March 2016 at Hacettepe University, Ankara, Turkey. 


\section{Introduction: Dystopia}

"Cruelty, injustice, intolerance and oppression. And where you had the freedom to object, to think and speak as you saw fit, you now have censors and surveillance coercing your conformity and soliciting submission" (McTeigue, 2006: 0:20:00-0:20:13), says $V$, the protagonist of $V$ for Vendetta, while he is explaining the situation of the citizens of England, in which the movie is set. This England seems to be a dystopian one like the Airstrip One, once known as England or Britain, in Nineteen Eighty-Four by George Orwell. Thus, it is not surprising that $\mathrm{O}^{\prime}$ Brien, one of the characters in Nineteen Eighty-Four, depicts his world as "the exact opposite of hedonistic Utopias that the old reformers imagined. A world of fear and treachery and torment" (Orwell, 2000: 306). This depiction is significant because dystopia, as a genre, emerges out of the impossibility of utopia, and it is translated as "not-good place." Accordingly, dystopias are fictional works set in an unpleasant future world where control is maintained through elements such as fear, surveillance and punishment. Although the context and elements of dystopias vary in accordance with the period in which they are written, perhaps almost all of them share a common trait: an oppressive regime that controls its citizens.

If it is taken into consideration that dystopias project the current political or social order into an almost disastrous future (Abrams, 1999: 328), then it will make sense that the dystopia as a literary genre began to appear especially after the World Wars, which are the biggest warning signs of a worsening world condition together with their devastating consequences. They became popular with the influence of the totalitarian regimes like Hitler's Germany and Stalin's Russia, and this popularity has reached its peak in the twenty-first century. Margaret Atwood (2005) finds it sad that what we have is not utopias but dystopias, and continues, "if enough people disagree with us we'll have to eliminate or suppress or terrorize or manipulate them, and then we've got 1984" (95). Therefore, it is possible for writers to warn the readers about imminent consequences of current political or social decisions, and to criticise a current political system, by fictionalizing their stories in dystopian worlds.

Dystopias are the portraits of societies having a seemingly perfect order, yet shaped by an imperfect, generally totalitarian rule. The ruling group in 
dystopias may be a political party or a religious community with a powerful leader on the top of it. The citizens are kept under such a control and are so oppressed that they do not have the right to speak and physical or psychological capacity to lead over any aspect of their lives. Yet, since fiction is not complete without a kind of conflict, dystopias almost always include dissident characters, generally the protagonists of the story, resisting the ruling system. These characters are different from other people in the society with their capacity to uncover the hidden truths behind this so-called perfect society or the real motives and aims of the rulers. Usually aided with at least one of the other characters, they try to bring the truths to the light, and bring about a change within the system. They sometimes become successful, at other times, they fail and the system prevails with people suffering and being oppressed by the totalitarian rule. In accordance with the characteristics of totalitarianism, this study concerns itself with the similarities and differences between two political systems in Nineteen Eighty-Four and $V$ for Vendetta by respectively dealing with the totalitarian party and the leader, ideology, terror, secret police, surveillance, propaganda and the place of art and literature in totalitarian systems. Although these characteristics are featured not only in these works, but also in other dystopias as well as satires revolving around totalitarian rule, this study focuses only on these two fictional works and aims to reveal how their creators prefer to handle totalitarian rule through their narratives.

\section{Totalitarianism}

The concept of "totalitarianism," which roughly means total power and control, was initially used by Italian philosophers and politicians in the 1920s when the fascist regime began to be dominant in Italy (Gregor, 2009). Journalist Giovanni Amendola, an opponent of the Italian fascism, first used the concept of "totalitarian" as a condemnation of that political system. On the other hand, in the writings of Giovanni Gentile, who regards himself as the philosopher of fascism, totalitarianism gained a positive meaning as a comprehensive ruling system in reference to Mussolini's fascist regime. Gentile mentions in "The Philosophic Basis of Fascism" (1928) about this comprehensive or totalitarian scope of fascism, and adds that it "concerns itself not only with political organization and political tendency, but with the whole will and thought and feeling of the nation" (299). However, Italian fascism is not the only regime which could be associated with totalitarianism either then or today. Nazi 
Germany and Soviet Russia, where the ultimate control and power of dictators like Adolf Hitler and Joseph Stalin over the masses can be observed, may also be examples of the totalitarian system. Indeed, asking for "total, unrestricted, unconditional, and unalterable loyalty of the individual member" (Arendt, 1976: 323), totalitarianism is based on the principle of a total control of the citizens, which includes not only political, but also social, economic, cultural and all other spheres of life.

Although definitions and explanations of totalitarianism vary in accordance with different thinkers' views, it is almost certain that in a totalitarian system, there is one political party in power led by one leader with a specific ideology (Friedrich \& Brzezinski, 1965; Linz, 2000). All the departments of the state from police to education are subject to this party, all the aspects of human life are under the party's control, all actions and speech of the citizens are observed and recorded by the party. In order to exercise a total power and control over the citizens, the party uses almost all means of communication and surveillance including media, cameras, telephones and microphones. Any action or speech that shows the slightest sign of disloyalty or even suspicion can be detected by the party immediately. As a result, those who are charged with treason are captured, tortured, and eliminated by the party. All these elements could be the defining characteristics of a totalitarian system. Likewise, Pauley lists several features of totalitarianism that people dealing with it generally put forward:

(1) the extraordinary powers of the leader; (2) the importance of an exclusionist ideology; (3) the existence of a single mass party; (4) a secret police prepared to use terror to eradicate all domestic opposition; (5) a monopoly of the communications media as well as over the educational systems; (6) a determination to change basic social, artistic, and literary values; and (7) an insistence that the welfare of the state be placed above the welfare of its citizens. (2015: 1)

Despite these highlighted features, some scholars object to the concept of totalitarianism, and assert that Hitler's Germany and Stalin's Russia were indeed not totalitarian but authoritarian regimes, by remarking that people in those countries were not subject to a total control, and they had freedom in their private lives. In this sense, totalitarian and authoritarian regimes are sometimes confused and the terms are interchangeably used, which seems to be a faulty approach. In authoritarianism, it is certain to see the monopoly of political power, yet it gives a chance to the citizens to live their private lives freely. On 
the other hand, totalitarianism desires control in all aspects of life, and penetrates into the most intimate parts of human life to the extent that you have nothing, as it is stated in Nineteen Eighty-Four, "except the few cubic centimetres inside your skull" (Orwell, 2000: 32).

Besides being a classic of dystopia genre, Nineteen Eighty-Four by Orwell is also important in showing how a totalitarian system exercises control over its people. Actually, Orwell's aim in writing Nineteen Eighty-Four is to depict how people may suffer and be oppressed in a totalitarian society. Disillusioned by the failure of socialism in creating justice and equality in Russia under the control of Stalin, Orwell strictly objected to totalitarianism explaining in his article "Why I Write" that "every line of serious work" that he wrote beginning from 1936 was "written, directly or indirectly, against totalitarianism" (Orwell, 1946: para. 11). Nineteen Eighty-Four with its legacy over the decades has inspired numerous dystopias, among which we can list $V$ for Vendetta, both the movie directed James McTeigue and the graphic novel with the same name written by Alan Moore and illustrated by David Lloyd. Moore (1990) lists Orwell, Huxley, Fahrenheit 451 as well as many others among the concepts that inspired him in the process of creating $\mathrm{V}$. The graphic novel actually began as a comic book series in the 1980s, a period when Margaret Thatcher was in office as the prime minister of the United Kingdom, with the fear that the oppressive rule under Thatcher may be one day grow into a totalitarian regime. Both Orwell's and Moore's visions that any oppressive regime seems to result in totalitarianism and to create a kind of dystopia lead them to criticise predominantly their own societies. Orwell's emphasis that "totalitarianism, if not fought against, could triumph anywhere" (Orwell, 1968: 502) including Britain is noteworthy as both Orwell and Moore aim not to denounce such a specific regime as fascism or socialism, but to condemn totalitarianism overall through their works.

\section{Party, Leader and Ideology}

The two dystopian worlds of Nineteen Eighty-Four and $V$ for Vendetta are similar in that they are both under the control of totalitarian parties. Being named after the year it is set, Nineteen Eighty-Four depicts London, the chief city of Airstrip One, which is one of the provinces of Oceania. The simply-called Party in charge of Oceania consists of two parts: Outer and Inner Party. While the members of the Inner Party are more privileged than the ones of the Outer Party, the proletarians in the country are excluded from both the rights and 
responsibilities of the Party members since they are considered the neutral element in the society. In the eye of the Party, the proletarians are the masses without the ability to think and go into action against it as their life is limited to "a diet of mass literature, heavy physical work, films, football, beer and gambling" (Claeys, 2010: 124). Even though the Party does not care about them, the proletarians actually form the majority of the population, compared to the members of the Party. This is not very surprising when it is taken into consideration that the totalitarian party, as Friedrich and Brzezinski (1965) write, is made of "a relatively small percentage of the total population (up to 10 percent) of men and women" (22). Nevertheless, the members of the Inner Party are loyal, or they seem to be loyal in the case of the Outer Party, to the Party, which can be a clue why the Party wants to keep the membership under control. The Party does not only desire the loyalty and dedication of its members, but it also seeks, in accordance with its total control, to penetrate into almost every aspect of the lives of citizens. In this sense, the Party keeps their lives in control through four different Ministries,

the four Ministries between which the entire apparatus of government was divided. The Ministry of Truth, which concerned itself with news, entertainment, education and the fine arts. The Ministry of Peace, which concerned itself with war. The Ministry of Love, maintained law and order. And the Ministry of Plenty, which was responsible for economic affairs. (Orwell, 2000: 6).

It is interesting to notice in the novel that the Ministry of Truth is responsible to alter the truths and justify them in such a way that they always support what the Party says or does, or the Ministry of Peace deals with waging wars.

The Party, indeed, comes to power through chaos resulting from a former war as Norsefire, the totalitarian ruling party in $V$ for Vendetta, succeeds in gaining power through creating chaos. Before coming to power Norsefire starts a detention project that involves all people who are thought by Norsefire to be dissidents and potentially dangerous. Gathering these people including "immigrants, Muslims, homosexuals, terrorists. Disease-ridden degenerates" (McTeigue, 2006: 0:03:50-0:03:58) in a research centre called Larkhill Medical Research Institute, prisoning, torturing and killing them to use them as test subjects, Norsefire wants to create a virus that would be a biological weapon. Although most of the subjects fail and die during the experiments, and the centre is destroyed by an explosion, Norsefire manages to develop the virus that is actually used on citizens of England. Norsefire releases the virus in three 
different areas: Three Waters Treatment and Supply Complex, St Mary's School and a tube station, which becomes sufficient to kill thousands of people. However, Norsefire obviously makes some religious extremists scapegoat for the biological attacks and causes eventually war and terror. As a consequence, an atmosphere of chaos and fear takes over England, from which Norsefire, under the leadership of Adam Sutler, benefits to seize the government: "Fear got the best of you. And in your panic, you turned to the now High Chancellor Adam Sutler. He promised you order, he promised you peace and all he demanded in return was your silent, obedient consent" (McTeigue, 2006: 0:20:44-0:20:55). This is exactly what Norsefire seeks to achieve by creating such conditions based on fear and terror which would lead citizens to submission for the sake of protection and restoration of order. Linz (2000) asserts that the reason why totalitarian parties appeal to terror is that they aim to sustain their total control, and, at the same time, they are afraid to lose the total control. Accordingly, Norsefire takes size of power and strives to make this power permanent by adopting those methods that induce terror, methods that demanded by Adam Sutler.

Norsefire cannot actually be distinguished from Adam Sutler in its motives and actions since one of the prominent characteristics of a totalitarian party is that it is ruled by one single person. Although Sutler is now the ultimate power both leading Norsefire and ruling over the country, he starts as "a young, up-and-coming politician," but he is also "completely single-minded and has no regard for the political process. The more power he attains, the more obvious his zealotry and the more aggressive his supporters become" (McTeigue, 2006: 1:33:00-1:33:17). After the biological attacks, Sutler makes a promise that his party would help the citizens and reconstruct peace and order in the country. Eventually, the election, which is held after the incidents, results in the victory of Norsefire by a landslide. Indeed, soon after the results of the election, a pharmaceutical company called Viodoxic finds a cure for the virus. What is striking here is that this company is controlled by prominent members of Norsefire who gain a big wealth as a consequence. It is understood, at last, "the goal of this [Larkhill] project is power. Complete and total hegemonic domination" (McTeigue, 2006: 1:33:32-1:33:36). While those party members become rich, and, additionally, are brought to prestigious posts, Adam Sutler, as the leader of Norsefire, is appointed to the newly created position of High Chancellor. Sutler is not only the leader of the party, but he is also "the leader" 
of the country, as Gregor (2012) expresses that totalitarian leaders are called "The Leader" who "embody the will of the community" (4). Sutler is regarded as the ultimate power in the country where his posters are on the walls of almost all buildings. At least, he seems to be the ultimate power until the end of the movie when he is betrayed and killed by his own man, Peter Creedy who is the chief of the secret police. The reason why Sutler is respectively a weak leader is partly because that he is an actual human being. This is also why he lives in an underground place with securities and he talks to even his men through video calls.

While Sutler does really exist, it is not known whether Big Brother, the leader of the Party in Nineteen Eighty-Four, is a real person or not. Though there is a possibility that he once might have lived, no one has seen him in recent years, and thus the reader cannot be sure about the existence of Big Brother. It is very probable that Big Brother is a figure or a myth that is made up by the Party. According to Friedrich and Brzezinski (1965), myths and symbolism have such a significant place that they justify the totalitarian rule "reinforcing the authority of those who are wielding power [the party and the leader] in a particular community" (91). Winston Smith, the protagonist of the novel, tries to remember when he heard about Big Brother for the first time, which is not likely for him to be certain about. Because the Party records that Big Brother has always been there since the beginning of the Party till now. In this sense, it is possible to consider Big Brother a legendary or mythical hero, who has always existed and will always exist, which makes him a much more powerful totalitarian leader than Adam Sutler. Big Brother's eyes are constantly watching everyone since there is almost nothing that does not show his face. He is everywhere "on coins, on stamps, on the cover of books, on banners, on posters and on the wrapping of a cigarette packet - everywhere. Always the eyes watching you and the voice enveloping you. Asleep or awake, working or eating, indoors or out of doors, in the bath or in bed - no escape" (Orwell, 2000: 31-32). It can be inferred that Big Brother is omnipresent, which means that he is present not only in all places but also at all times. When Winston asks $\mathrm{O}^{\prime}$ Brien, an important member of the Inner Party, if Big Brother really exists in the same way as Winston himself exists, O'Brien replies that Big Brother exists no matter in what way Winston thinks he exists. Similarly, in response to the question whether Big Brother will ever die, O'Brien says it is not likely that Big Brother can die. Big Brother exists as the Party exists; he is "the embodiment of the Party" (Orwell, 2000: 296) and the symbol of the Party's ideology. 
The ideology of the Party, called Ingsoc, is obscure as there is uncertainty about its nature and the beginning of the word's usage. Ingsoc is the version of English Socialism that is valid in Newspeak, the language used in Oceania. Despite this name, the Party is neither English nor socialist though it pretends to be socialist boasting that the Party ended capitalism and class distinction. This is actually just a deception with the aim of controlling the citizens more easily as ideology becomes a tool used by the totalitarian parties and leaders to justify their actions. An ideology is simply "a reasonably coherent body of ideas concerning practical means of how to change and reform a society" though totalitarian ideology becomes related to destroying a society and building a new one (Friedrich \& Brzezinski, 1965: 88). With respect to this understanding of ideology, neither the name "Ingsoc" in particular nor what it evokes is not that important in the same way as the ideologies of other two superpowers in the world, Eurasia and Eastasia, along with Oceania are not important. Because all these ideologies "are barely distinguishable, and the social systems which they support are not distinguishable at all. Everywhere there is the same pyramidal structure, the same worship of semi-divine leader, the same economy existing by and for continuous warfare" (Orwell, 2000: 226). In spite of the Party's "socialist" ideology, there is still class distinction in Oceania between the proletarians and the Party members, and injustice and inequality even among the Party members. Moreover, the proletarians are reduced to the level of animals as it says in one of the Party slogans: "Proles and animals are free" (Orwell, 2000: 83). This is, of course, because of the Party's approach to the proletarians as the masses without the capacity to go into action.

On the other hand, Norsefire does not need to hide its exclusionist ideology, most probably fascism, in terms of its treatment toward different groups of people in society that do not conform to the norms. When it is compared to Ingsoc including such principles as doublethink and Newspeak, Norsefire's ideology seems less elaborate both in its nature and approach to lives of citizens. Nevertheless, whether it is elaborate or not, the ideology of a totalitarian regime becomes, after accepted by the party, the absolute truth imposed on citizens who are also expected to accept it without questioning. In this way, as Orwell claims, totalitarianism "not only forbids you to express even to think - certain thoughts, but it dictates what you shall think, it creates an ideology for you, it tries to govern your emotional life as well as setting up a code of conduct" (1941: para. 4). Norsefire's fascism is mixed with religious 
fundamentalism resulting in its discrimination against such groups as immigrants and Muslims on the basis of national origin and religion. This exclusionist ideology is better understood when a homosexual woman named Valerie Page, who is one of the victims in Larkhill, tells how things become frightening with the rule of Sutler. She remembers "how the meaning of words began to change [...] how 'different' became dangerous. I still don't understand it why they hate us so much" (McTeigue, 2006: 1:16:36-1:16:59) It is because those groups of people, who are "different" and not "normal," are considered by Norsefire a possible threat to the welfare of the country and maintenance of Norsefire's power, and they should be eliminated, which is accomplished through Larkhill project. What is more horrifying here that Norsefire does not only imprison, torture and kill them through experiments, it also does not hesitate to kill thousands of citizens including children and people who seem not to be "different" via the virus. It is clear to note that terror becomes a crucial method of maintaining power in totalitarian ideology of Sutler and Norsefire.

\section{Terror, Secret Police and Surveillance}

Although terror is not always included in the definitions of totalitarianism (Linz, 2000), it would not be wrong to state that terror is one of the remarkable elements of the totalitarian regimes. As it is expressed before, terror is used by the totalitarian party in order to sustain its power and control that they are afraid to lose. Friedrich and Brzezinski (1965) explain that terror is,

whether physical or psychic, effected through party and secret-police control, supporting but also supervising the party for its leaders, and characteristically directed not only demonstrable "enemies" of the regime, but against more or less arbitrarily selected classes of the population; the terror whether of the secret police or of party-directed social pressure systematically exploits modern science, and more especially scientific psychology. (22)

It can be understood that terror does not have to be physical, it may also influence the psychology of those on whom terror is exercised, whether they are enemies of the totalitarian party, or the citizens, or even the party members. The psychological terror used by the totalitarian party for total control may take the form of "the threat of execution or with defamation and social shame" in order to "intimidate" and "frighten" those people who are seen possible threats to the maintenance of the total control, and to bring them under "conformity and obedience" (Friedrich \& Brzezinski, 1965: 129). So, one of the primary goals of terror is to make the citizens conform to the norms and rules imposed by the totalitarian party on them by showing them what will happen otherwise. When 
Norsefire and Adam Sutler in $V$ for Vendetta see the possibility that the citizens may rebel against them, Sutler wants his men to give a message of threat to people: "I want this country to realize that we stand on the edge of oblivion. I want every man, woman and child to understand how close we are to chaos. I want everyone to remember why they need us" (McTeigue, 2006: 1:30:211:30:34). Similarly, in Nineteen Eighty-Four, O'Brien tells Winston that terror will always exist in Oceania: "The espionage, the betrayals, the arrests, the tortures, the executions, the disappearances will never cease. It will be a world of terror as much as a world of triumph" (Orwell, 2000: 307). Terror in both $V$ for Vendetta and Nineteen Eighty-Four is generally exercised by a kind of secret police that is a group of police-like officers whose identities are not revealed.

The Fingermen are the secret police in $V$ for Vendetta, who spy the citizens and capture those who are detected as suspicious or guilty. The audience sees the Fingermen for the first time at the beginning of the movie when Evey Hammond, one of the main characters, is confronted by three Fingermen in a street after the curfew. It is thought at first that the Fingermen are doing their job by catching those like Evey who break the curfew. Yet, it is later understood it does not actually matter whether people break the curfew or not as they attempt to rape Evey without listening to what she says. Here, the Fingermen are portrayed as corrupt and not-very-clever men. It is not known for sure whether all the Fingermen are like the ones who attack Evey or not. However, it is expected them to be at least clever to the extent that they detect people taking suspicious actions. Under the head of Peter Creedy, the Fingermen capture such people, which is called "black-bag," and imprison, question, torture and kill them in the end. Throughout the movie, the audience is shown that various characters including Evey's parents who attend riots after Adam Sutler become High Chancellor, and Gordon Deitrich, a homosexual television programmer who humiliates Sutler in his talk show, are black-bagged. Evey herself is saved by $\mathrm{V}$ from being captured by the police and the Fingermen after she helps $\mathrm{V}$, who is declared a terrorist. $V$ tells her that she would be captured and taken into interrogation: "They'd imprison you, torture you, and in all probability, kill you in the pursuit of finding me" (McTeigue, 2006: 0:28:57-0:29:02). When the Fingermen black-bag a person who is regarded as a dissenter, even the police are not able to reach and/or interrogate that person. The Fingermen aim not to reform and correct such people by punishing them, but to eliminate and get rid of them. 
Like the Fingermen, the Thought Police in Nineteen Eighty-Four is responsible for capturing people regarded dangerous to the authority of the Party. Those who are captured and arrested by the Thought Police are found guilty for having committed the thoughtcrime. It is possible to note that thoughtcrime is the biggest crime in Oceania, it "IS death" (Orwell, 2000: 33) since it is the source of all other crimes:

Whether he wrote DOWN WITH BIG BROTHER, or whether he refrained from writing it, made no difference ... He had committed ... the essential crime that contained all others in itself. Thoughtcrime, they called it. Thoughtcrime was not a thing that could be concealed for ever. You might dodge successfully for a while, even for years, but sooner or later they were bound to get you. (Orwell, 2000: 22)

The Party aims to prevent the citizens from committing crime even in their minds as it wants to make people internalise power and control imposed on them. Those who are detected by the Party to commit crime one way or another, namely whether actually committing it or considering about committing it, are caught and got rid of by the Thought Police. Winston knows that most people who vanish actually fall into the hands of the Thought Police. The significant thing is that those people are treated as if they have never existed, and they are regarded not as lost or dead, but as "unpersons." Before they become unpersons they are tortured and tormented by the Party not just to simply punish them but to "cure" them, in other words to make them fit into the norms. When Winston is captured, O'Brien tells him the reason: "To cure you! To make you sane! ... The Party is not interested in the overt act: the thought is all we care about. We do not merely destroy our enemies, we change them" (Orwell, 2000: 289-290). O'Brien explains that the Party predominantly cares about what people think rather than what they actually do, which is why thoughtcrime is the greatest of all crimes.

In order to prevent the citizens from committing thoughtcrime, the Party keeps them under surveillance in every possible way. In addition to the Thought Police and spies observing people, there are telescreens in public places and in all Party members' houses both broadcasting and recording audio and video. However, although they are always on, it is not known if they record all the time, or when they record. Thus, citizens assume that they are being watched at any moment, which causes them to internalise power exercised by the Party while they live "in the assumption that every sound you made was overheard, and, except in darkness, every movement scrutinized" (Orwell, 2000: 5). Norsefire 
also uses surveillance through various ways including cameras and phones to both control citizens and to gain information. The government is fully organized to take care of surveillance and is divided into different departments responsible for various ways of surveillance. The audio methods related to surveillance are under the responsibility of the department called "the ear" while the visual ones are up to the division called "the eye." Therefore, devices used for surveillance that record audio and video are also referred to as ears and eyes. It is interesting that these divisions are named after the parts of the human body according to their responsibilities. Correspondingly, as it is stated above, the secret police are referred to as "the finger" since they are responsible for dealing with "criminals." On the other hand, the standard police forces are responsible for investigations and are called "the nose." And the duty of the department which is called "the mouth" is to propagandise Sutler and Norsefire's policies.

\section{Propaganda and Art}

Both Norsefire in $V$ for Vendetta and The Party in Nineteen Eighty-Four do not exercise their power only through terror and surveillance, but also through propaganda since it is vital for almost all totalitarian parties to maintain their power (Friedrich \& Brzezinski, 1965: 131). Totalitarian parties can use almost everything in their favour as a tool for propaganda including media. In $V$ for Vendetta, Norsefire's propaganda operate even before Sutler's victory in the election held after the biological attacks. "Fueled by the media," the propaganda campaign of Norsefire makes it possible that "fear and panic spread quickly fracturing and dividing the country until" people have no other choice but to trust Sutler in order to be saved from chaos (McTeigue, 2006: 1:34:34-1:34:42). Norsefire does not reveal the truth about the attacks making fabricated news that charge religious extremists. Accordingly, Norsefire uses media for propaganda in order to justify its actions and to show people Adam Sutler and his party are capable of knowing and controlling information. British Television Network (BTN), the national TV network, is at Sutler's command, and one of the biggest tools for propaganda. Besides the man, Dascombe, who is the head of the mouth is also responsible for managing BTN. When V explodes the Old Bailey, the Central Criminal Court in England, to draw public's attention to initiate his plan against Sutler and Norsefire, BTN informs the citizens that it is an emergency demolition under the government's control: "We're calling it an emergency demolition. We have spin coverage on the network and throughout 
the InterLink. Several experts have been lined up to testify against the Bailey's structural integrity" (McTeigue, 2006: 0:11:31-0:11:41). Norsefire does not want citizens to know that it is exploded by $\mathrm{V}$, someone considered a terrorist, as it would be bad for the authority and reputation of Norsefire if people knew the truth. For the same reason, the murder of Lewis Prothero, a propagandist who is called "the Voice of London," by V is announced on BTN news as a natural death "from apparent heart failure" (McTeigue, 2006: 0:37:45). In this sense, Norsefire and the Party not only change or remove truths, but they also create their own realities that match their actions and desires.

In Nineteen Eighty-Four, the propaganda and fabricated news become so systemised that the Party controls almost all truths in Oceania, and, if necessary, transforms them especially through media. The Party changes every bit of information in accordance with its benefit; the past news, for instance, are continuously altered and adjusted according to present needs, which is called the mutability of the past: "Day by day and almost minute by minute the past was brought up to date" (Orwell, 2000: 47). As it is expressed before, the Ministry of Truth is responsible for these continuous alterations. If any piece of news, record or information conflict with what the Party currently says, then it is either erased or adjusted to present. Sometimes, it is even possible that "fictional records of nonexistent persons or events" are made up "to help to support the Party line" (Booker, 1994: 212). Statements that are consistent with the adjusted information take their place not only in telescreens, radios and newspapers, but also in other publications. For example, it is shown on the news that Oceania, which was at war with Eastasia and at peace with Eurasia four years ago, is currently at war with Eurasia and at peace with Eastasia, and it is accepted that the situation was the same four, even ten years ago. The remarkable point is that people believe or seem to believe in the fact that Oceania has always been at war with Eurasia: "And if all others accepted the lie which the Party imposed - if all records told the same tale - then the lie passed into history and became truth" (Orwell, 2000: 40). Accordingly, the Party is capable to control past, present and future by altering the truth and dominating people's thoughts.

One of the major ways of control that both the Party and Norsefire apply in regard to propaganda is to control culture and art. Culture becomes a tool of power and control rather than a mixture of diverse customs, habits, lifestyles, ways of entertainment and fields of art. In totalitarian regimes, "art is viewed in utilitarian rather than aesthetic terms and is considered to be an instrument in 
shaping the ... society" (Friedrich \& Brzezinski, 1965: 329). Literary works, films, or musical scores are efficiently used so that they are able to make the Party propaganda in Nineteen Eighty-Four. In addition to propagandising its politics through such media, the Party already supplies "the citizens of Oceania with newspapers, films, textbooks, telescreen programmes, plays, novels - with every conceivable kind of information, instruction, or entertainment, from a statue to a slogan, from a lyric poem to a biological treatise" (Orwell, 2000: 50). In this way, the Party shapes the social and cultural lives of the citizens as well as imposing its own ideology on them. This social, cultural and artistic supply is operative both for the Party members and the proletarians at different levels. As the proletarians are considered "helpless, like the animals" (Orwell, 2000: 309), they are engaged with different materials other than the ones intended for the Party members. They include "rubbishy newspapers containing almost nothing except sport, crime and astrology, sensational five-cent novelettes, films oozing with sex, and sentimental songs which were composed entirely by mechanical means on a special kind of kaleidoscope known as a versificator" (Orwell, 2000: 50). Even though things related to sex and sexuality except procreation are not permitted, the proletarians are able to read and watch porn, which the Party members are not allowed to see at all. Similarly, Norsefire in $V$ for Vendetta censors works of art and literature as well as other kinds of stuff that are found objectionable. Such censored paintings, sculptures, jukeboxes, etc. are collected and either destroyed or stored up by the government. V "reclaims" some of those things "from the vaults of the Ministry of Objectionable Materials" and brings them into his home that he calls "the Shadow Gallery" (McTeigue, 2006: 0:27:51-0:28:07). Gordon Deitrich also collects artistic works such as photographs and books including a Quran that he finds aesthetic and attractive. Sometimes, the censored works do not only include "objectionable materials" because they are considered unfit for Norsefire's ideology. They may also be blacklisted just because High Chancellor Adam Sutler does not enjoy as with Tchaikovsky's 1812 Overture which is used by V during the explosion of the Old Bailey. Sutler does not want to hear it again since it reminds him that the explosion is highly probably a sign of resistance to his totalitarian rule.

\section{Conclusion: The Problem of Resistance}

Both Nineteen Eighty-Four and $V$ for Vendetta are fictional works that speculate about future; however, they reflect real concerns over contemporary 
societies where people are oppressed and forced to conform to numerous norms being kept under control and surveillance. Dystopias correspondingly function as a warning that such oppression, conformity, control and surveillance could result in totalitarianism. After all, these dystopias are predominantly inspired by the rising dictatorships in the 1930s and several oppressive regimes in the twentieth century. It would not be wrong to express that Big Brother has resemblances to Stalin, or Norsefire has similar beliefs with the Nazi Party. Yet, this does not mean that these works directly deal with and attack Stalin or Nazism. Rather they reflect totalitarianism distinctively presenting totalitarian rules different from one another. They also present the problem of resistance to the totalitarian rules, which forms a notable issue in the analysis of totalitarianism, in dissimilar ways. According to Friedrich and Brzezinski (1965), "there remain in all these dictatorships some groups that manage to offer some resistance to the totalitarian rule" despite the total control of such states (279). They explain that various motives and impulses such as "moral indignation and thwarted ambition, religious scruples and personal revenge, patriotic fervor and class antagonism" and many others may lead to acts of resistance (280). Those acts of resistance may contain one or a few individuals whose small and unorganized actions do not succeed at making a difference as in Nineteen EightyFour. Or, they may be much bigger ones leading to a movement that can end the totalitarian rule as in $V$ for Vendetta. Although both Winston Smith and V, as the protagonists and the centres of resistance in the novel and the movie, do not get involved in something like a resistance group - Winston does not actually become a part of the resistance movement called the Brotherhood, he is just duped by O'Brien - V's resistance brings the end of Norsefire while Winston fails. One of the reasons of this failure may be the difference between the characters of $\mathrm{V}$ and Winston.

In the movie, $\mathrm{V}$ is portrayed like a superhero, who defeats Sutler and Norsefire, kills all his enemies, saves people of England from "bad guys", and enables them to reach freedom. V, indeed, is one of the prisoners in Larkhill during the biological researches, and also responsible for the explosion that destroys the centre. He actually becomes a quasi-superhuman through the effect of biological experiments. Seeking vengeance over Norsefire and those people who are involved in the Larkhill project, $V$ makes plans to kill most of them who become important figures in the country such as Sutler, Creedy and Prothero. Nevertheless, $\mathrm{V}$ does not only want to punish and kill whoever is responsible for the project, but he also desires to bring back justice and freedom to England. 
Inspired by the Gunpowder Plot and Guy Fawkes, V explodes the Old Bailey on November 5, and plans to destroy the House of Parliament one year after in a similar way. Addressing the citizens, $\mathrm{V}$ also wants them to support and stand beside him outside the gates of the Parliament building. When Evey questions him whether it is helpful to explode the buildings, $\mathrm{V}$ answers that "building is a symbol, as is the act of destroying it. Symbols are given power by people. Alone a symbol is meaningless, but with enough people, blowing up a building can change the world" (McTeigue, 2006: 0:32:30-0:32:41). Throughout the movie, V hides his face with a Guy Fawkes mask and covers all his body with dark clothes, partly due to his deformed skin, but mainly due to his desire to present himself as a symbol of an idea rather than mere flesh and blood.

Unlike V, Winston Smith is just an ordinary human being with all his weaknesses. Working in the Ministry of Truth as responsible for altering the news in newspapers in accordance with the Party's interests, Winston is a member of the Outer Party. Although he seems to be a loyal Party member, he hates and does not support the rule of the Party and Big Brother, always wondering whether somebody else thinks in the same way as he does. As an act of resistance, he decides to write a diary in his house hiding from the telescreen, with the hope that one day people will learn the truths about the Party: "To the future or to the past, to a time when thought is free, when men are different from one another and do not live alone - to a time when truth exists and what is done cannot be undone" (Orwell, 2000: 32). Later, he notices that his superior O'Brien in the workplace may also be down with the Party and Big Brother. Winston's resistance reaches its peak when $\mathrm{O}^{\prime}$ Brien explains that he is a member of the Brotherhood and gives Winston the book of Emmanuel Goldstein who is the Brotherhood's leader. As Winston reads Goldstein's book, he becomes more conscious of how the Party seizes and maintains power and control, and more eager to resist the Party's rule. He does not expect that the Party can be defeated in a short time, but he imagines "little knots of resistance springing up here and there-small groups of people banding themselves together, and gradually growing, and even leaving a few records behind, so that the next generations can carry on where we leave off" (Orwell, 2000: 179). However, Winston's hopes crush as $\mathrm{O}^{\prime}$ Brien reveals to be a spy and have trapped Winston, which is resulted in the capture of Winston by the Thought Police. 
The difference between the results of V's and Winston's acts of resistance also shapes the endings of the movie and the novel. The difference becomes striking especially when it is known that $V$ for Vendetta was partly inspired by Orwell's narrative. On the one hand, V initiates change by revealing the truths, manages to get rid of Sutler and other leading figures of Norsefire and to start a revolution. Even though he dies at the end of the movie, Evey completes what he leaves undone, and the House of Parliament is destroyed with the attendance of thousands of citizens. Indeed, this kind of ending seems to be typical Hollywood scenario of victory as in most superhero movies. Yet, it gives the message that there is hope for the future since England is very likely to be saved from the totalitarian rule. On the other hand, Winston Smith is detected by the Party, captured and physically and psychologically tortured by the Thought Police. Though he tries to maintain his resistance against the Party, he is eventually defeated when he is taken over by his phobia of rats. At the end of the novel, Winston, broken by the Party, embraces the totalitarian rule of the Party and Big Brother, which makes his earlier attempts of resistance futile. It can be understood that there is no hope for the future in Nineteen Eighty-Four as the novel ends with the statement that "he loved Big Brother" (Orwell, 2000: 342).

Accordingly, it is significant that this difference between the two endings reflect diverse speculations about what future holds in real life. Having once experienced totalitarianism, as in Hitler's Germany or in Stalin's Russia, human beings adopt different approaches to current problems such as the oppression of fundamental rights and freedoms that have the potential to lead them to the same point. Being optimist, some believe that humanity has learned its lesson from totalitarian dictatorships and other oppressive regimes and will not make the same mistakes. Others have rather dark and bleak visions that history will repeat itself and the world will turn into a dystopia, since greed for power is intrinsic to human beings. Therefore, it is important to realize flaws and defects in society today and to improve the living conditions before what people have actually turns into Nineteen Eighty-Four. 


\section{References}

Abrams, M. H. (1999). A Glossary of Literary Terms (7th ed.). Boston, MA: Heinle\&Heinle.

Arendt, H. (1962). The Origins of Totalitarianism (7th ed.). Cleveland, OH: Meridian Books.

Atwood, M. (2005). Writing with Intent: Essays, Reviews, Personal Prose: 1983-2005. New York, NY: Carroll and Graf Publishers.

Booker, M. K. (1994). Dystopian Literature: A Theory and Research Guide. Westport, CT: Greenwood Press.

Claeys, G. (2010). "The Origins of Dystopia: Wells, Huxley and Orwell". G. Claeys (Ed.), The Cambridge Companion to Utopian Literature. New York, NY: Cambridge University Press, 107-131.

Friedrich, C. J., \& Brzezinski, Z. K. (1965). Totalitarian Dictatorship and Autocracy (2nd ed.). Cambridge, MA: Harvard University Press.

Gentile, G. (1928). “The Philosophic Basis of Fascism”. Foreign Affairs, 6 (2), 290-304.

Gregor, A. J. (2009). Marxism, Fascism and Totalitarianism: Chapters in the Intellectual History of Radicalism. Stanford, CA: Stanford University Press.

Gregor, A. J. (2012). Totalitarianism and Political Religion: An Intellectual History. Stanford, CA: Stanford University Press.

Linz, J. J. (2000). Totalitarian and Authoritarian Regimes. Boulder, CO: Lynne Rienner Publishers.

McTeigue, J. (Director), Silver J., Hill, G., Wachowski, L., \& Wachowski, L. (Producers). (2006). V for Vendetta [Film; Netflix]. United States: Warner Bros. Pictures.

Moore, A. (1990). "Behind the Painted Smile". KC Karlson (Ed.), $V$ for Vendetta. New York, NY: DC Comics, 267-276.

Orwell, G. (1941). "Literature and Totalitarianism". https:// www.orwell.ru/library/articles/totalitarianism/english/e_lat 
Orwell, G. (1946). "Why I Write". https:/ / orwell.ru/library/essays/wiw/english/e_wiw

Orwell, G. (1968). The Collected Essays, Journalism and Letters of George Orwell (4th vol.). London, England: Secker \& Warburg.

Orwell, G. (2000). Nineteen Eighty-Four. London, England: Penguin Books.

Pauley, B. F. (2005). Hitler, Stalin, and Mussolini: Totalitarianism in the Twentieth Century (4th ed.). Chichester, England: Wiley Blackwell. 